\title{
EPIZOOTIOLOGICAL OBSERVATIONS ON MALIGNANT CATARR- HAL FEVER AND TRANSMISSION OF THE DISEASE IN BUFFALO CALVES (BUBALUS BUBALIS)
}

\author{
G. SINGH, B. SINGH, P. P. GUPTA, D. S. HOTHI
}

Department of Veterinary Bacteriology and Virology and Department of Veterinary Pathology College of Veterinary Science, Punjab Agricultural University, Ludhiana (India)

Received May 15, 1978

\begin{abstract}
Singh G., B. Singh, P. P. Gupta, D. S. Hothi: Epizootiological Observations on Malignant Catarrhal Fever and Transmission of the Disease in Buffalo Calves (Bubalus bubalis). Acta vet. Brno, 48, 1979: 95-103.

The epizootiology of malignant catarrhal fever (MCF) in buffaloes and cattle in India is reported. Successful experimental transmission from natural MCF cases to buffalo calves was made in two serial passages. Attempts to infect the rabbits and to isolate a viral agent in bovine thyroid and other tissue cultures failed.
\end{abstract}

Blood, tissue cultures, postmortem examination, cattle, buffaloes, experimental transmission.

Bovine malignant catarrhal fever (MCF) has been recognised in various parts of the world (Blood and Henderson 1974). In India, while describing the first authenticated report of MCF Parihar et al. (1975) indicated that the disease was recorded as early as 1941 on the basis of the course and postmortem lesions in cattle and goats (Annual Reports, Imperial Veterinary Research Institute, $1941-42,42-46$ ) and on the clinical evidence in a Jersey Sindhi cross bred bull by Gnanaprakasam (1969).

This paper describes the epizootiology of the disease in India and experimental transmission of MCF to healthy buffalo calves from natural cases of MCF in buffaloes and cattle and limited attempts to isolate virus in rabbits and in various primary tissue cultures.

\section{Materials and Methods}

The material for experimental inoculation consisted of whole blood, prescapular lymph node, liver, kidneys, spleen, adrenals and thyroid tissues from natural cases of MCF in buffaloes and cattle with symptoms of ,head and eye" form of the disease. The blood was collected in sodium citrate and was inoculated as such without delay whereas the tissues were cut into small pieces and ground in pestle and mortar and suspended in tenfold volume of phosphate buffered physiological saline containing $500 \mathrm{I}$. U./ml penicillin and $5 \mathrm{mg} / \mathrm{ml}$ streptomycin. The blood and tissue suspensions were inoculated into buffalo calves by different routes of inoculation following the dosage schedule as given in Table 1. The buffalo calves used in the experiment were in good health and were obtained from the villages free from the disease. Two uninfected buffalo calves were used as controls and were kept along with the infected group. All buffalo calves were observed daily and their rectal temperatures recorded twice a day.

The inoculated buffalo calves which developed clinical signs and pathological lesions of MCF were used as a material donors for further passage work. The passages of the infective agent are tabulated (Table 1).

The diagnosis of MCF in this study was based on gross and histopathological changes. Detailed postmorten examination of some of the natural cases and experimental cases when died or sacrificed was conducted. For microscopic examination, tissue pieces from various organs were collected in 10 per cent formalin and 5-6 microns thick paraffin sections were stained with haematoxylir and eosin. 
Table 1

Experimental transmission of malignant catarrhal fever from naturally infected cases to buffalo calves

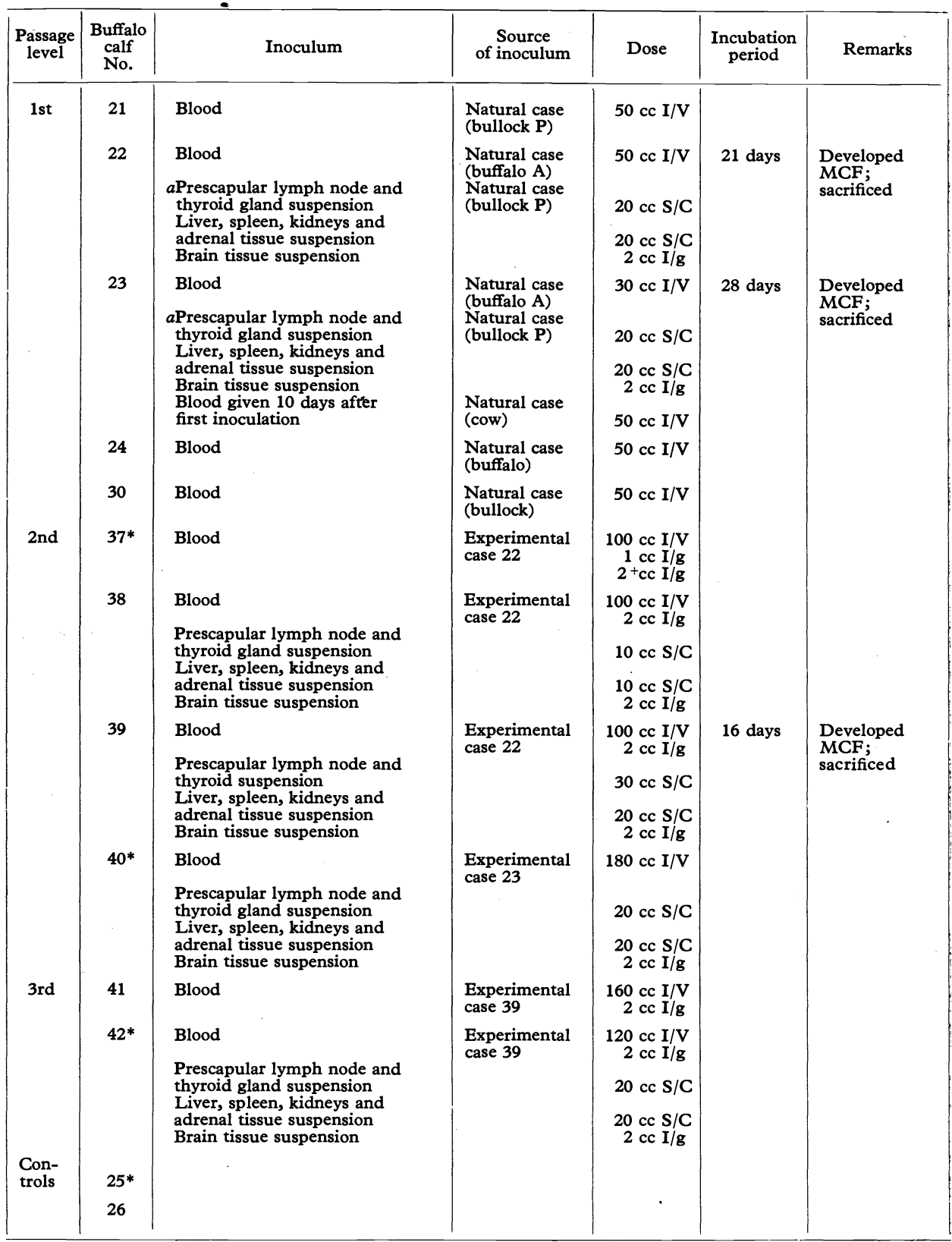

$\mathrm{I} / \mathrm{V}=$ Intravenously, $\mathrm{S} / \mathrm{C}=$ Subcutaneously, I/g = Intraglandularly (prescapular lymph gland)

$a$ Tissues collected about 10 hours after death of animal.

+ The inoculum given 1 day after first inoculation.

* Animals sacrificed for virus isolation attempts and pathological diagnosis. 
The washed buffy coat derived from blood of six naturally infected cases and two experimental cases was injected into rabbits in $0.5 \mathrm{ml}$ quantities intravenously, using one rabbit for each case. In addition, 10 per cent lymph node suspension was injected intraperitoneally of subcutaneously in a dose of 3 to $5 \mathrm{ml}$. In two instances, the additional inoculation of buffy coat $0,25 \mathrm{ml}$ per rabbit intracerebrally was also carried out. Rectal temperatures of rabbits were taken daily for 50 to 70 days.

The buffy coat was also inoculated onto primary buffalo calf thyroid, adrenal, kidney and testicular tissue monolayers grown in tubes, using standard Hank's saline supplemented with 0.5 per cent lactalbumin hydrolysate, 0.1 per cent yeasteolate and 10 per cent goat serum. In the maintenance medium, 2 per cent goat serum was used and the medium changed twice weekly. The monolayers were maintained up to 20 days and were checked regularly for evidence of a cytopathic effect. Lamb testicular tissue monolayers were also inoculated.

\section{Results}

Epizootiology: During the year 1974, 31 buffaloes and cattle were reported to have suffered from MCF at one village (Kalala, Sangrur) and all the animals died. The maximum cases occurred during the months of March, April and May, 1974. No case was recorded in the months of January, July, August, October and December, 1974. The chronological order of occurrence of cases was more or less similar to that noted during the year 1973 (Fig. 1). Continued sporadic mortality has been reported at the same locality for 3 to 4 years even before 1973 (Parihar et al. 1975). In February and April, 1975, two animals developed MCF and died. Thereafter, no fresh cases were reported up to July, 1976. Thus, during the year 1975, only two cases of MCF were seen in comparison to 31 in 1974 and 86 in 1973. Only one case was noted at another village Badbar which is situated about $40 \mathrm{~km}$ from Kalala. The investigation revealed that this particular animal

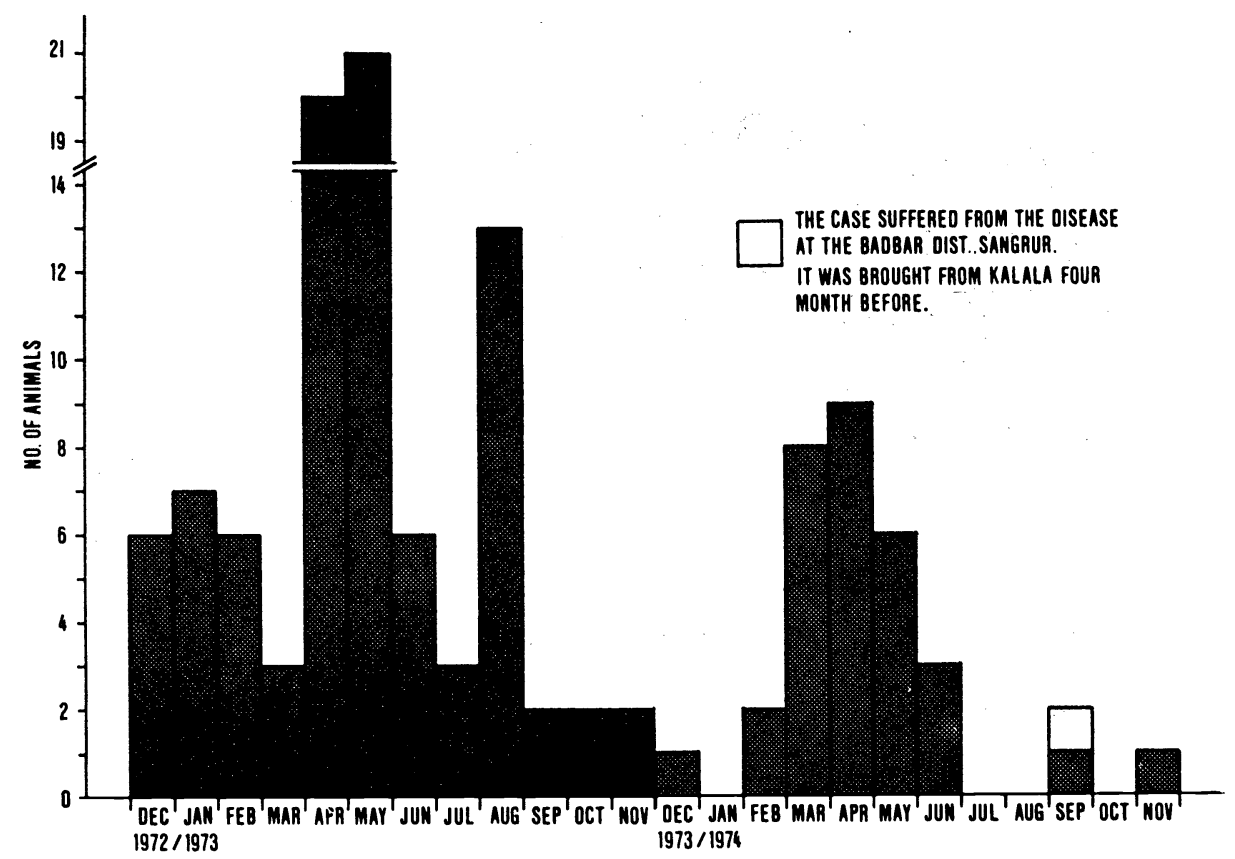

Fig. 1 
was also brought from Kalala and developed symptoms similar to MCF after four months and died. The incubation period in this particular case thus appeared to be more than four months.

In April and May, 1975, an outbreak of MCF appeared in another village

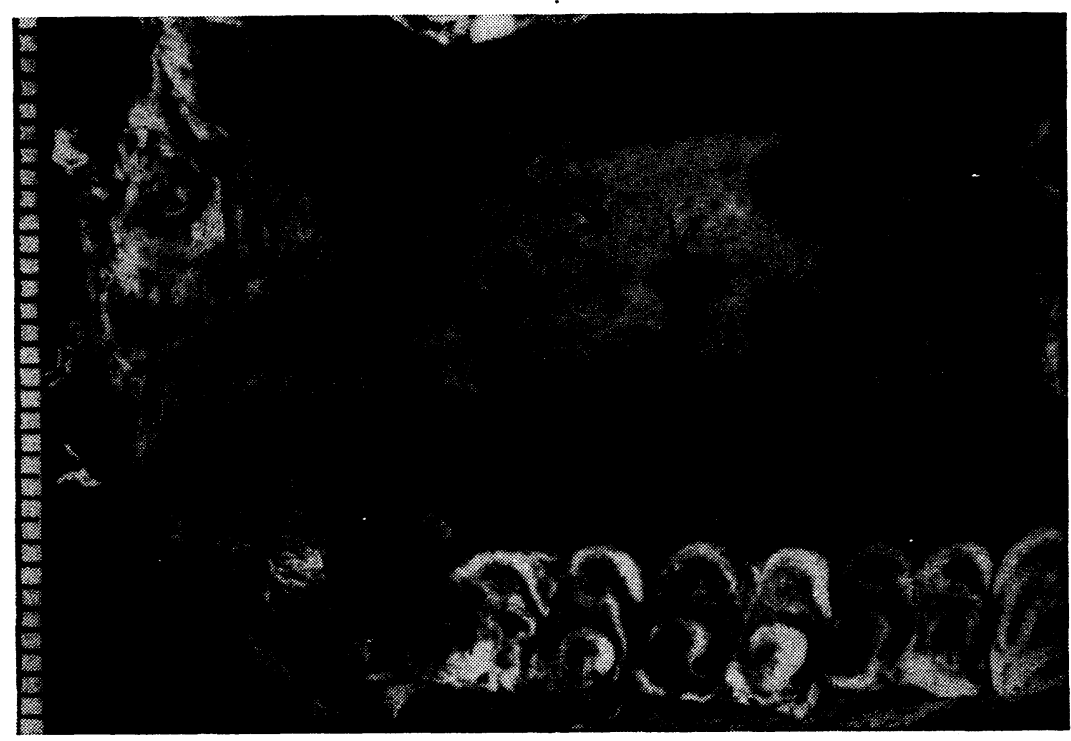

Fig. 2

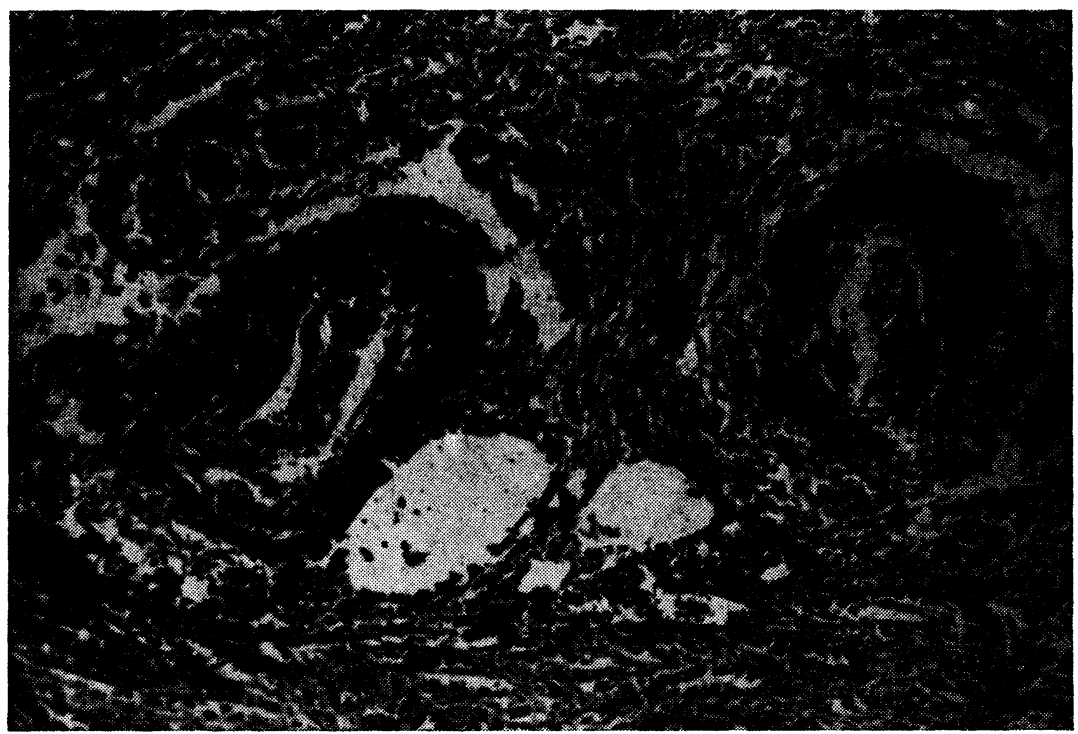

Fig. 3 
(Chuhanke Kalan, a place about $2 \mathrm{~km}$ from Kalala). About 12 buffaloes and cattle were affected with illness and died.

The breeding flocks of sheep were said to exist in both the villages since long time. The history revealed that most of the affected animals invariably came in contact with sheep either by mixed grazing or otherwise.

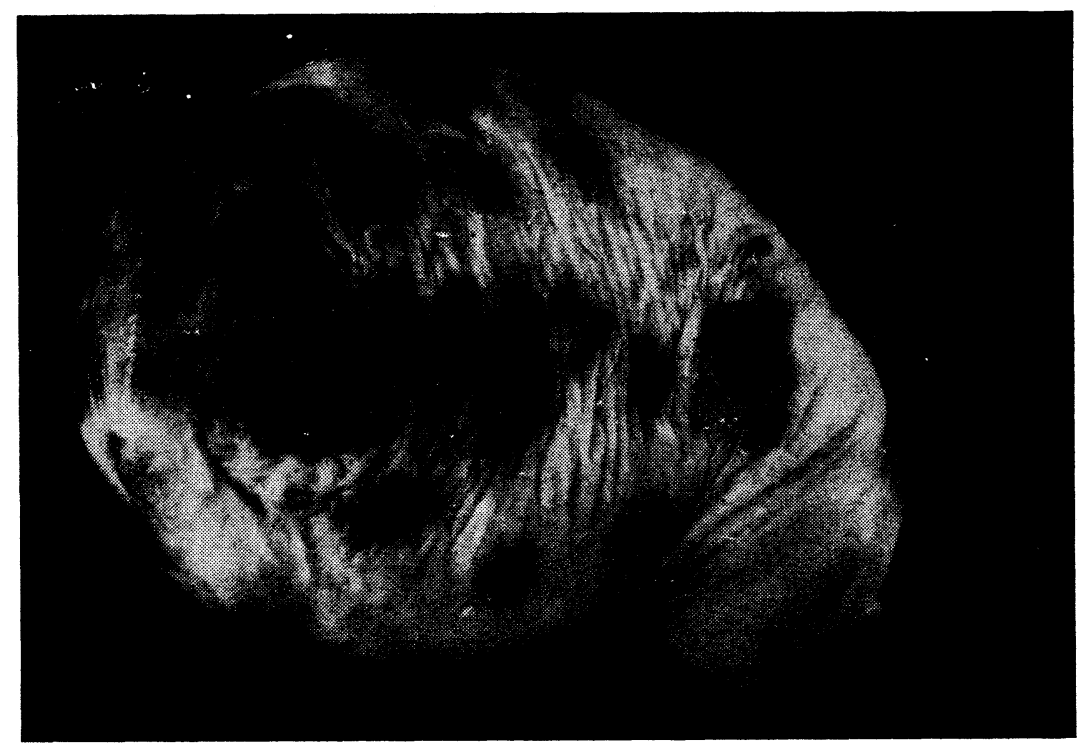

Fig. 4

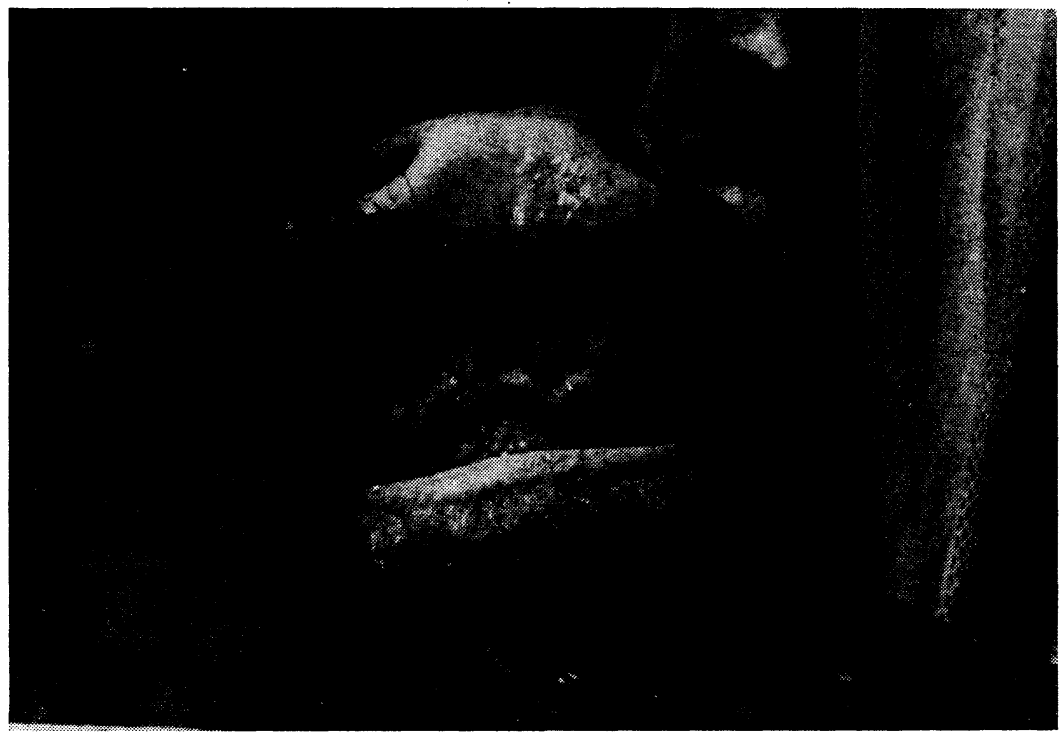

Fig. 5 
The clinical symptoms seen in natural cases of MCF were anorexia, high rise of temperature, dullness, depression, dropping saliva, mucopurulent nasal and ocular discharge and staggering gait. Corneal opacity was also seen. Some animals had diarrhoea. There was a rapid deterioration with a marked tendency to lie down. The course of the disease was found to be 3 to 7 days. In a few cases, it ranged between 8 and 20 days. Usually, one to three animals were sick at a time. The morbidity therefore at any one time was low. However, over a longer interval, it was quite high.

On necropsy, gross lesions were almost comparable in all the cases and included variable sized haemorrhages and ulcers over the gums, udder, the tongue, on the mucosa of cheeks, hard palate (Fig. 2), pharynx, larynx, oesophagus, abomasum and intestines. All the visceral organs and the brain and meninges were highly congested. Diffuse haemorrhages were seen in the mucosa of urinary bladder, intestines and upper respiratory tract. All the lymph nodes were enlarged, oedematous and had haemorrhages on cut surfaces.

The predominant microscopic lesion in all the organs was vasculitis characterised by swelling, hyperplasia and desquamation of endothelial cells, necrosis in the tunica media and infiltration of reticular cells, plasma cells, lymphocytes and macrophages in and around the tunica adventitia (Fig. 3) Severe congestion was seen in all the organs. The lymph nodes showed oedema and hyperplasia of lymphoid and reticulo-endothelial cells. In eye, inflammatory cell reaction and oedema was seen in iris. Liver and cardiac muscle showed degenerative changes.

Experimental transmission: Among the five buffalo calves inoculated with blood and tissue suspension from naturally infected cases, two developed symptoms similar to MCF. The incubation period in one case was 21 days and in the other 28 days. Both the calves were sacrificed when in moribund condition. The blood and tissues were collected and given to four more healthy buffalo calves. One buffalo calf developed signs of MCF after 16 days of incubation. In all the three experimental cases of MCF (two in first passage and one in second passage), the temperature rose abruptly (up to $106.8^{\circ} \mathrm{F}$ ). There was anorexia, dullness and depression. Serous nasal discharge and congestion of oral mucosa were evident. Over the next 2 to 3 days, the nasal discharge became mucopurulent: and the oral mucosa was marked with ulcers. The conjunctivae were congested and a mucopurulent ocular discharge was seen. One animal showed slight opacity of the cornea. Prescapular.lymph nodes were enlarged. In all the cases, there was: a rapid progress of the disease, the animals becoming recumbent within 48 hours: of first being noticed ill. The animals were sacrificed at 3 to 4 days after the onset of illness for further passage work and virus isolation attempts. Of the two. buffalo calves inoculated with blood and tissue suspension from the second passage experimental case, one died suddenly 27 days post-inoculation without showing relevant symptoms from causes unknown and the other animal did not show any clinical signs when observed as long as 148 days of infection.

Postmorten examination of the three experimental buffalo calves, which had developed the clinical signs of MCF, revealed ulcers on the gums and abomasum, severe congestion of all the visceral organs and brain including the meninges, haemorrhages in the intestine, urinary bladder (Fig. 4) and other mucous membranes (Fig. 5). All the lymph nodes were enlarged (Fig. 6), oedematous and their cut surface showed haemorrhages.

On microscopic examination, the most striking change in all the organs was vasculitis of the small blood vessels characterised by marked hypertrophy and 
hyperplasia of the endothelial cells leading to occlusion of their lumen. The tunica media showed thickening due to hyperplasia of smooth muscle cells. The outer media and tunica adventitia were infiltrated with macrophages, lymphoid cells and reticular cells at places leading to perivascular cuffing (Fig. 7). The lymph

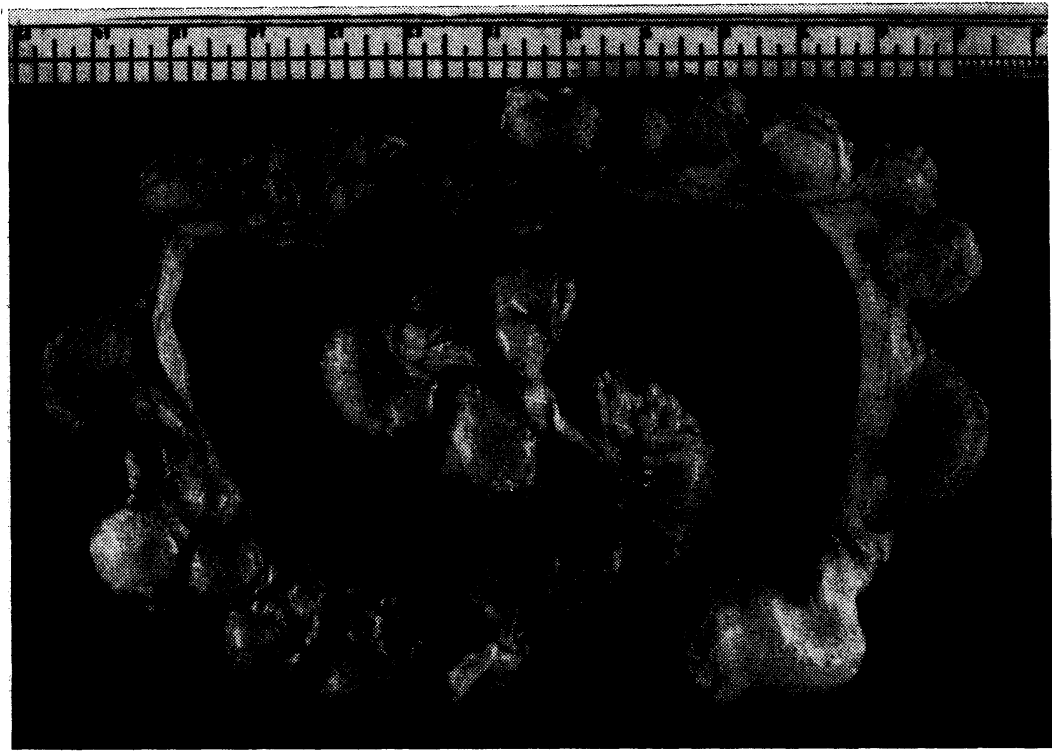

Fig. 6

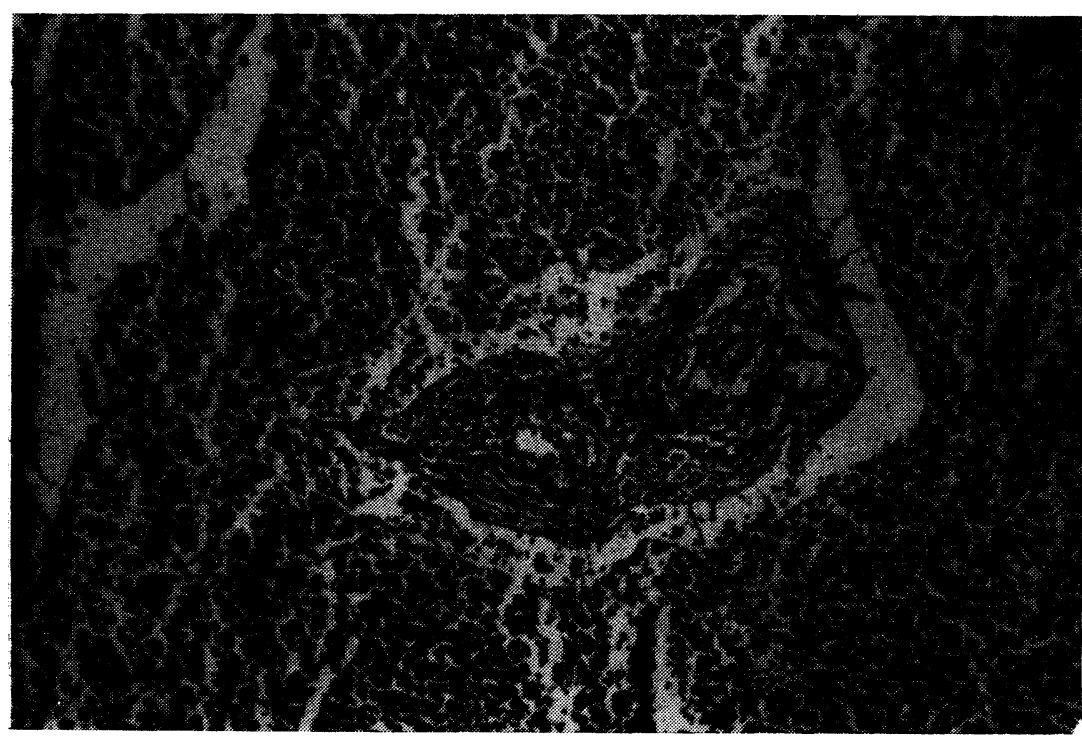

Fig. 7 
nodes showed marked hyperplasia of lymphoid tissue, particularly the lymphoblasts and oedema. Liver showed infiltration of lymphoid cells and other mesenchymal cells in the portal triads and degenerative changes in the hepatic cells. In kidneys, there was coagulative necrosis of tubular epithelial cells, and in lungs, there was marked hyperplasia of mesenchymal cells in the interalveolàr septa leading to their thickening.

The control animals were clinically normal during the period of observation. On necropsy, no gross or microscopic lesions of MCF were seen.

Blood and lymph node tissue suspension from naturally infected cases of MCF and experimentally induced MCF cases did not induce clinical signs of disease in rabbits. Limited work in the primary bovine thyroid cultures and various other tissue cultures infected with buffy coat derived from blood of MCF cases failed to reveal any cytopathic effect. Also, no cytophatic virus was obtained in thyroid autogenous cultures.

\section{Discussion}

In areas outside Africa, there is a large amount of epizootiological evidence which suggests that sheep may play an important part in the maintenance and spread of the MCF disease. The causal agent is transmitted by inapparently infected sheep to cattle (Plowright 1968). In the present investigation, the breeding flocks of sheep have been found in existence in both the villages since long time. Thus the possibility of sheep acting as carriers and responsible for transmission of the disease cannot be ruled out.

A characteristic feature of the epizootiology of MCF in the present study is the persistence of infection in only one village (Kalala) since 1970 and its failure to spread to adjoining places except in April and May, 1975 when about 12 cases were recorded in another village Chuhanke Kalan, about $2 \mathrm{~km}$ from Kalala. This outbreak could have followed as a result of the movements or transfer of sheep from Kalala where MCF was endemic.

The experimental transmission of MCF of probable ovine origin has always been a matter of considerable difficulty (Plowright 1968). The maximum number of passages in calves that have been affected with sheep-associated MCF is 5 (Pierson et al. 1974). Horner et al. (1975) also transmitted the disease but passage to a second calf was unsuccessful. In the present experiment, the infective agent caused disease in buffalo calves in two serial passages and was transmitted to 3 out of 9 buffalo calves. It is the first time that this has been achieved in this country.

The first indication of illness in experimental animals was a high rise of temperature. The characteristic feature of the condition was the rapid progress of the disease, the animals becoming recumbent and very sick within 48 hours of first being noticed ill.

The incubation period in experimental buffalo calves of the first passage was 21 days in one case and 28 days in the other. The buffalo calf of the second passage had shown clinical signs 16 days after inoculation but its blood and tissue suspension did not induce MCF further in the two buffalo calves inoculated. The clinical signs, gross and microscopic lesions of the disease in experimental buffalo calves were similar to those seen in natural cases in the present study and to those reported in the literature (Plowright 1968; Parihar et al. 1975). The diagnosis of the disease was based on histopathological lesions, mainly vasculitis, as has been done by Parihar et al. (1975). 
Limited work to isolate virus in bovine thyroid and other tissue cultures failed to reveal a cytopathic viral agent. This results and the failure to reproduce the disease in rabbits are disappointing but are in keeping with the experience of various workers (Plowright 1968).

\section{Epizootologie maligni katarální horečky a přenos nemoci na telata buvolů (Bubalus bubalis)}

V práci byla sledovaná epizootie maligní katarální horečky u buvolů a skotu $\mathbf{v}$ Indii.

Byl popsán úspěšný přenos nákazy a dvojí pasážování viru na experimentálně infikovaných telatech buvolů. Pokus o infekci králíků a izolaci viru na bovinní štítné žláze a jiných tkáňových kulturách nebyl úspěšný.

\section{Эпизоотология элокачественной катаральной горячки и перенос заболевания на телята буйволов (Bubalus bubalis)}

В работе проводились исследования эпизоотии элокачественной катаральной горячки у буйволов и крупного рогатого скота в Индии.

Был описан успешный перенос инфекции и двойная прививка вируса экспериментально инфицированным телятам буйволов. Попытка проведения инфекции кроликов и изоляции вируса на щитовидной железе крупного рогатого скота и других культурах тканей не завершилась успехом.

\section{Acknowledgements}

Thanks are due to the Dean, College of Veterinary Science, Punjab Agricultural University, Ludhiana and the District Animal Husbandry Officer, Sangrur for providing the facilities.

\section{References}

Annual Rep. Imp. Vet. Res. Instt. Mukteswar and Izatnagar (India) for 1941-42 and 1942-46 cited by Parihar et al., 1975.

BLOOD, D. C. - HENDERSON, J. A.: Veterinary medicine, Bailliére Tindall and Cox, London 4th edition, 1974, pp. $491-494$.

GNANAPRAKASAM, V.: Malignant head catarrh - A case report. Indian Vet. J., 46, 1969: 912-916.

HORNER, G. W. - OLIVER, R. E. - HUNTER, R.: An epizootic of malignant catarrhal fever. 2. Laboratory investigations. New Zealand Vet. J. 23, 1975: 35-38.

PARIHAR, N. S. - RAJYA, B. S. - GILL, B. S.: Occurrence of malignant catarrhal fever in India. Indian Vet. J., 52, 1975: 857-859.

PIERSON, R. E. - STORZ, J. - MCCHESNEY, A. E. - THAKE, D.: Experimental transmission of malignant catarrhal fever. Amer. J. Vet. Res., 35, 1974: 523-525.

PLOWRIGHT, W.: Malignant catarrhal fever. J. Amer. Vet. Med. Assoc., 152, 1968: 795-804. 